\title{
Response of growth, yield and quality of small onion (Allium cepa L. var. aggregatum don.) to Tamil Nadu Agricultural University-Water Soluble Fertilizers (TNAU-WSF)
}

\section{Vairavan}

Department of Soil Science and Agricultural Chemistry, Tamil Nadu Agricultural University, Coimbatore - 641003 (Tamil Nadu), India

\section{S. Thiyageshwari*}

Department of Soil Science and Agricultural Chemistry, Tamil Nadu Agricultural University, Coimbatore - 641003 (Tamil Nadu), India

\section{P. Malarvizhi}

Department of Soil Science and Agricultural Chemistry, Tamil Nadu Agricultural University, Coimbatore - 641003 (Tamil Nadu), India

\section{T. Saraswathi}

Department of Vegetable Science, Tamil Nadu Agricultural University, Coimbatore - 641003 (Tamil Nadu), India

${ }^{*}$ Corresponding author. Email: thiyageshwari@gmail.com

\section{Article Info}

https://doi.org/10.31018/

jans.v13i4.3055

Received: September 25, 2021

Revised: November 9, 2021

Accepted: November 13, 2021

\section{How to Cite}

Vairavan, C. et al. (2021). Response of growth, yield and quality of small onion (Allium cepa L. var. aggregatum don.) to Tamil Nadu Agricultural University-Water Soluble Fertilizers (TNAU-WSF). Journal of Applied and Natural Science, 13(4), 1350 - 1356. https://doi.org/10.31018/jans.v13i4.3055

\begin{abstract}
Enhancing the food production for the growing world population has needed application of highly sustainable and efficient inputs to produce more food per unit of land. Hence, Tamil Nadu Agricultural University (TNAU), Coimbatore, Tamil Nadu has produced Water soluble fertilizers (WSF) in its maiden attempt and it is necessary to optimize on different crops. Small onion is one of the most important vegetables in the Indian diet and it has high demand but low productivity. To enhance crop productivity and quality of small onions, the application of TNAU-WSF was taken up. A field experiment was laid out in a Randomized block design (RBD) incorporating 8 treatments comprising of application of RDF at $100 \%$ NPK as TNAU WSF, soil test based application of $75 \%, 100 \%, 125 \%$ NPK ha ${ }^{-1}$ as TNAU-WSF with soil application of sulphur (S) and foliar spray of TNAU Liquid multi micronutrient (LMM) and without S and TNAU LMM and absolute control. Each treatment was replicated thrice with onion (CO 4). Soil test based application of $125 \%$ NPK ha ${ }^{-1}$ as TNAU-WSF with sulphur (S) and TNAU LMM recorded significantly higher in plant height $(54.01 \mathrm{~cm})$, the number of leaves per bulb $(8.56)$, leaf greenness $(67.5 \mathrm{SPAD})$, root length $(5.42 \mathrm{~cm})$, polar bulb diameter $(4.38 \mathrm{~cm})$, equatorial bulb diameter $(2.72 \mathrm{~cm})$ fresh bulb weight $(74.21 \mathrm{~g})$, bulb yield $\left(1751 \mathrm{t} \mathrm{ha}{ }^{-1}\right)$ and quality attributes

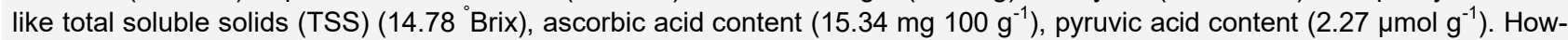
ever, soil test based application of $100 \% \mathrm{NPK} \mathrm{ha}^{-1}$ as TNAU-WSF was found to be an ideal rate to attain the economic target yield of the onion crop.
\end{abstract}

Keywords: Fertigation, TNAU Liquid multi micronutrient (TNAU LMM), Soil test based fertilizer application, TNAU-WSF, Water soluble fertilizers

\section{INTRODUCTION}

Fertilizer feeds the globe by feeding the crops through the soil. Fertilizers play a vibrant role in food production and are a critical input for fruits and vegetables (Stewart and Dibb, 2005). Due to an increasing population, fertilizers were applied abysmally to boost up agri- cultural and horticultural production. The fertilizer consumption rate of India increased to $7.26 \%$ in $2019-20$ compared to the previous year (Agricultural Statistics at a glance, 2020). High yield crop production and its related inputs have come under forceful scrutiny over the past several years because of their accountable effects on the environment. Sustainable development in agri- 
culture, including horticultural production, is necessary for social, national, and economic progress in the context of the growing global population and guaranteed access to food and nutritional security. So, optimal use of resources such as fertilizers, water, and soil will support sustainability.

Fertigation is a solution to encounter the global demand and minimize the environmental hazards, as the inefficient and increased use of chemical fertilizers can create environmental risks (Malhotra, 2016). Fertigation can save nutrient dose and water from 40 to $60 \%$ over conventional irrigation methods (Dingre et al., 2015). Apart from better use efficiency, the yield can be increased by $15-40 \%$ over surface irrigation (Tripathi et al., 2017). Fertigation allows adequate supplies of water and nutrients with specific timing and even distribution to meet the crop nutrient demand. Further, fertigation guarantees considerable saving in fertilizer usage and decreases leaching losses (Mmolawa and Or, 2000).

Following China, India is the world's largest onion producer. The productivity of onion in India is $18.1 \mathrm{t} \mathrm{ha}^{-1}$ which is low compared to the world average. The demand for onions also increases every year. In 20122013, the demand was 182.28 MT and 205.31 MT in 2017-18 (India Statistics, 2018). Numerous factors influence the production of onion. Inappropriate nutrient management and water are the main limiting factors affecting crop production (Jain et al., 2014). Hence, it is necessary to optimize the TNAU-WSF, according to the fertigation schedule to increase the growth, yield, and quality of small onion (Allium cepa L. var. aggregatum Don.).

In Tamil Nadu Agricultural University, Coimbatore, at the Department of Soil Science \& Agricultural Chemistry, Water soluble fertilizers (WSF) are produced at 19:19:19 \% of $\mathrm{N}, \mathrm{P}, \mathrm{K}$. Therefore, the present study aimed to assess the efficacy of TNAU-WSF on small onion.

\section{MATERIALS AND METHODS}

\section{Elucidation of the study area}

A field experiment was conducted with aggregatum onion var. $\mathrm{CO} 4$ at farmer's field near Devarayapuram in Thondamuthur $\left(11^{\circ} 01 \mathrm{~N}\right.$ latitude, $76^{\circ} 8^{\prime} \mathrm{E}$ longitude, and $315 \mathrm{~m}$ altitude), Coimbatore district, Tamil Nadu. Experimental site has mean annual rainfall of $952 \mathrm{~mm}$ and average minimum and maximum temperatures were $17^{\circ} \mathrm{C}$ and $38^{\circ} \mathrm{C}$. Maximum rainfall was received between October to December (India Meteorological Department, 2021). The soil of the experimental site was sandy clay loam and the initial soil parameters were listed in Table 1.

\section{Description of experimental materials}

Fertilizers were recommended based on soil test value. Following three developed STCR equations (Eq.1,2,3) from the Crop production guide - Horticulture (2020), TNAU was used to finalize the treatments of the experiment.
$\mathrm{FN}=0.99 \mathrm{~T}-0.34 \mathrm{SN}$
Eq.1
$\mathrm{FP}_{2} \mathrm{O}_{5}=0.58 \mathrm{~T}-0.76 \mathrm{SP}$
Eq. 2
$\mathrm{FK}_{2} \mathrm{O}=0.67 \mathrm{~T}-0.23 \mathrm{SK}$
Eq.3

The required fertilizer nitrogen ( $F N$ ), fertilizer phosphorus (FP), and fertilizer potassium (FK) for small onion were calculated by substituting the initial soil values of $\mathrm{N}, \mathrm{P}, \mathrm{K}$, and target yield in the STCR equation of small onion. The target yield for small onion was fixed at $16 \mathrm{t}$ $\mathrm{ha}^{-1}$. The seed bulbs were sown in a raised bed with the spacing of $20 \times 10 \mathrm{~cm}$ and the plot size was 20 sq.m $(5 \times 4 \mathrm{~m})$. TNAU-WSF were applied through fertigation according to the fertigation schedule mentioned in the Crop production guide - Horticulture, (2020) of TNAU. Sulphur was applied at $40 \mathrm{~kg} \mathrm{ha}^{-1}$ at 30 DAS and TNAU Liquid multi micronutrient at $1 \%$ was sprayed thrice at $30,40,50$ DAS.

\section{Treatment details}

Eight treatments with three replication in a randomized block design viz., $\mathrm{T}_{1}$ - Recommended dose of fertilizer (60:60:30 of NPK $\mathrm{kg} \mathrm{ha}^{-1}$ ) at $100 \%$ NPK as TNAUWSF, $T_{2}$ - Soil test based application of $75 \%$ NPK as TNAU-WSF , $T_{3}$ - Soil test based application of $100 \%$ NPK as TNAU-WSF, $T_{4}$ - Soil test based application of $125 \%$ NPK as TNAU-WSF, $T_{5}$ - Soil test based application of TNAU-WSF at $75 \%$ NPK + Sulphur (S) at $40 \mathrm{~kg}$ $\mathrm{ha}^{-1}+$ Foliar Spray (FS) of TNAU Liquid multi micronutrient (LMM) at $1 \%, \mathrm{~T}_{6}$ - Soil test based application of TNAU-WSF at $100 \%$ NPK $+S$ at $40 \mathrm{~kg} \mathrm{ha}^{-1}+\mathrm{FS}$ of TNAU LMM at $1 \%, T_{7}$ - Soil test based application of TNAU-WSF at $125 \% \mathrm{NPK}+\mathrm{S}$ at $40 \mathrm{~kg} \mathrm{ha}^{-1}+\mathrm{FS}$ of TNAU LMM at $1 \%$ and $T_{8}$ - Absolute control.

\section{Data collection and analysis}

The small onion was harvested at full maturity stage and bulb yield was recorded after neck cutting. Five representative plant samples were taken to record ob-

Table 1. Initial soil parameters of the experimental site at farmer's field

\begin{tabular}{ll}
\hline Organic carbon $\left(\mathrm{g} \mathrm{kg}^{-1}\right)$ & 5.3 \\
$\mathrm{pH}$ & 7.18 \\
$\mathrm{EC}\left(\mathrm{dSm}{ }^{-1}\right)$ & 0.05 \\
Available $\mathrm{N}\left(\mathrm{kg} \mathrm{ha}^{-1}\right)$ & 153 \\
Available $\mathrm{P}\left(\mathrm{kg} \mathrm{h}^{-1}\right)$ & 39 \\
Available $\mathrm{K}\left(\mathrm{kg} \mathrm{ha}^{-1}\right)$ & 210 \\
Available $\mathrm{S}\left(\mathrm{mg} \mathrm{g}^{-1}\right)$ & 14 \\
DTPA-Fe $\left(\mathrm{mg} \mathrm{g}^{-1}\right)$ & 6.91 \\
DTPA-Mn $\left(\mathrm{mg} \mathrm{g}^{-1}\right)$ & 5.38 \\
DTPA-Cu $\left(\mathrm{mg} \mathrm{g}^{-1}\right)$ & 0.48 \\
DTPA-Zn $\left(\mathrm{mg} \mathrm{g}^{-1}\right)$ & 0.68 \\
\hline
\end{tabular}


servations on growth, yield parameters, and biochemical analysis of ascorbic acid, pyruvic acid, allicin,and total phenols. Leaf greenness was measured with SPAD (Soil Plant Analysis Development, SPAD-502) meter. Total Soluble Solids (TSS) was estimated using a hand refractometer (ERMA, Tokyo, Japan). Pyruvic acid content ( $\mu$ moles/g fresh weight) was analyzed through the dinitro phenylhydrazine (DNPH) reagent method, which was modified and developed by Anthon and Barrett (2003). Ascorbic acid was estimated as per the method given by the Association of Official Analytical Chemists (1975).

\section{Statistical and economic analysis}

The analysis of variance for sets of data on growth, yield, and quality with significance level $p<0.05$ was done with AGRES software. The least square different (LSD) was used to separate the significantly differed mean. The Benefit Cost Ratio (BCR) was calculated using Eq.4 for every treatment to identify an economically better treatment.

$$
B C R=\frac{\text { Gross return }}{\text { Cost of cultivation }}
$$

\section{RESULTS AND DISCUSSION}

\section{Effect of TNAU-WSF on Growth and Growth attributes of Small Onion}

\section{Plant height}

The analysis of variance showed that the plant height (Table 2) of small onion was influenced by different fertigation levels of NPK with TNAU-WSF. By increasing fertigation level from $75 \%$ to $125 \%$ NPK, plant height was increased significantly. In this experiment plant height of small onion was ranged from $34.75 \mathrm{~cm}$ to $54.01 \mathrm{~cm}$. Maximum plant height was recorded in fertigation of $125 \%$ NPK as TNAU-WSF with $S$ at $40 \mathrm{~kg}$ $\mathrm{ha}^{-1}+$ TNAU LMM at $1 \%$ (FS) $\left(\mathrm{T}_{7}\right)(54.01 \mathrm{~cm})$, which was on par with Soil test based application of $125 \%$ NPK as TNAU-WSF $(51.94 \mathrm{~cm})\left(\mathrm{T}_{4}\right)$. Minimum plant height was recorded in the absolute control plot (34.75 $\mathrm{cm})\left(\mathrm{T}_{8}\right)$. According to Amare (2020), onion is an unbranched and shallow-rooted crop. Hence, onions respond effectively to the addition of more nutrients. So, the application of $\mathrm{N}$ at a higher dose could be attributed to an increase in plant height of small onion. This might be due to the constructive effect of nitrogen on vegetative growth and act as a "building block" of many compounds, viz., amino acids and proteins as reported earlier (Weil, 2017). Application of sulphur at $40 \mathrm{~kg} \mathrm{ha}^{-1}$ enhanced the growth of crop by improving photosynthesis and $\mathrm{N}$ uptake, as reported by Ozkan et al. (2018). Also, the application of TNAU LMM enhances plant growth by improving plant metabolism.

\section{Number of leaves per bulb}

The number of leaves per bulb (Table 2) increased significantly with an increase in fertigation level from $75 \%$ to $125 \%$ NPK as TNAU-WSF. Soil test based application of $125 \%$ NPK as TNAU-WSF with $S$ at $40 \mathrm{~kg}$ $\mathrm{ha}^{-1}+$ TNAU LMM at $1 \%(\mathrm{FS})\left(\mathrm{T}_{7}\right)$ recorded the maximum number of leaves per bulb (8.56) and it was on par with Soil test based application of $125 \%$ NPK as TNAU-WSF (8.41) $\left(T_{4}\right)$. The minimum number of leaves per bulb was recorded in absolute control (5.81) $\left(T_{8}\right)$. The increase in the number of leaves with further increase in Soil test based application of nitrogen from $75 \%$ to $125 \%$ could be attributed to greater photoassimilate production, good vegetative growth, and better cell division. The increase in the number of leaves was due to the enhanced synthesis of amino acids and chlorophyll by the addition of sulphur and micronutrients to the small onion. Comparable results were reported by Meher et al. (2016).

\section{Leaf greenness}

Soil test based application of $125 \%$ NPK as TNAUWSF with $S$ and TNAU LMM at $1 \%\left(\mathrm{~T}_{7}\right)$ (Fig. 2) recorded maximum SPAD reading in all three stages of crop growth. The SPAD reading increased during the initial stage of the crop and decreased during the harvesting stage. As $\mathrm{N}$ application increased, chlorophyll $\mathrm{a}$ and $\mathrm{b}$ contents were enhanced that in turn recorded higher SPAD reading. These results were in line with Gonçalves et al. (2019) and Hou et al. (2021)

\section{Root length}

From the analysis of variance, it was observed that root length (Table 2) was significantly influenced by different fertigation levels from $75 \%$ to $125 \%$ NPK as TNAUWSF. Root length was ranged from 3.95 to $5.42 \mathrm{~cm}$. The maximum root length was observed with $\left(T_{7}\right)$ : Soil test based application of $125 \%$ NPK as TNAU-WSF with $S$ and TNAU LMM at $1 \%(5.42 \mathrm{~cm})$. Minimum plant height was observed in the absolute control plot $(3.95 \mathrm{~cm})\left(T_{8}\right)$. According to Weil (2017), root growth is stimulated by the application of nitrogen and phosphorus. Hence, the root length of the onion was increased with an increased level of fertigation. Improved root growth was observed in treatments with foliar spray of TNAU LMM at $1 \%$. These findings have been corroborated with the findings of Ballabh et al. (2012), Acharya et al. (2015).

\section{Effect of TNAU-WSF on Yield and Yield attributes of Small Onion}

\section{Equatorial and polar diameter}

Bulb diameter (Table 2) was significantly influenced by soil test based application of TNAU-WSF from $75 \%$ to 


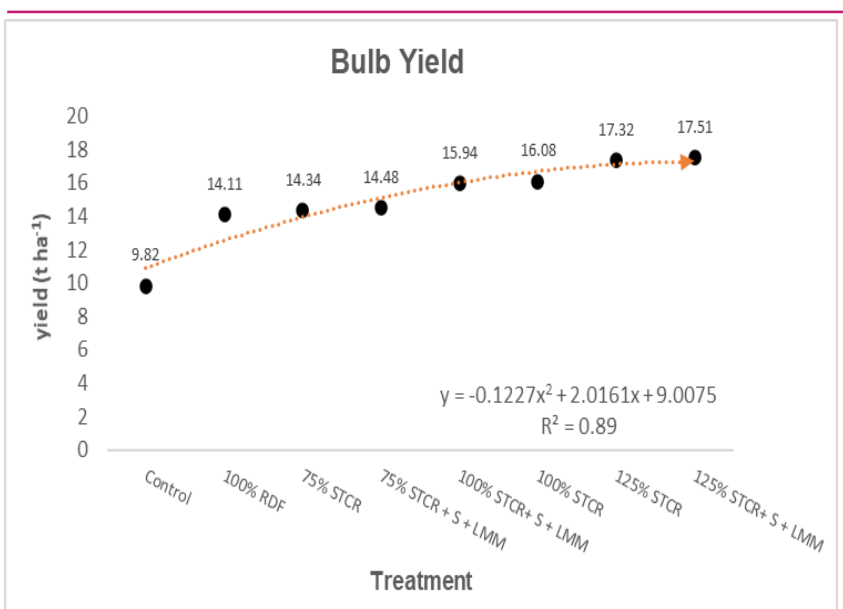

Fig. 1. Fertigation of TNAU-WSF on Yield (t ha- $\left.{ }^{-1}\right)$ of small onion

$125 \%$ NPK. Soil test based application of $125 \%$ NPK as TNAU-WSF with sulphur and TNAU LMM $\left(\mathrm{T}_{7}\right)$ recorded maximum equatorial $(2.72 \mathrm{~cm})$ and polar $(4.38$ $\mathrm{cm}$ ) diameter, which was on par with $\left(\mathrm{T}_{4}\right)$ soil test based application of $125 \%$ NPK as TNAU-WSF. The low equatorial (1.89) and polar (2.93) diameter was recorded in the absolute control plot $\left(T_{8}\right)$. Because of higher nutrient availability, higher bulb polar and equatorial diameter was achieved in fertigation with TNAUWSF. Solanki et al. (2020) observed similar findings of higher bulb diameter at fertigation with $100 \%$ RDF. Increased dose of potassium application improves the diameter of bulbs as reported by Sawale et al. (2018). In addition to potassium, the sulphur application could also be a reason for achieving a higher bulb diameter due to the increased rate of photosynthesis.

\section{Fresh bulb weight}

The ANOVA showed that different fertigation levels with TNAU-WSF significantly influenced fresh bulb weight (Table 2). Maximum fresh bulb weight was recorded in soil test based application of $125 \%$ NPK as TNAU-WSF with sulphur and TNAU LMM $(74.21 \mathrm{~g})\left(\mathrm{T}_{7}\right)$ and soil test based application of TNAU WSF at $125 \%$ NPK was on par with $T_{7}$, recorded fresh bulb weight of $72.5 \mathrm{~g}$. Minimum fresh bulb weight was recorded in absolute control (40.52g) $\left(\mathrm{T}_{8}\right)$. Increased fertigation of NPK as TNAU-WSF and sulphur at $40 \mathrm{~kg} \mathrm{ha}^{-1}$ to onion might increase net assimilation rate hasten the photosynthates of bulbs and bulb weight of onion.

\section{Bulb Yield}

The analysis of variance revealed a significant effect of different fertigation level of TNAU-WSF on onion bulb yield (Table 2). The yield increased with increase in fertigation level from $75 \%$ to $125 \%$ of NPK and has a quadratic $\left(\mathrm{R}^{2}=0.89\right)$ relationship (Fig.1) with treatments. The bulb yield ranged from 9.82 to $17.51 \mathrm{t} \mathrm{ha}^{-1}$. Maximum yield was recorded in $\left(T_{7}\right)$ soil test based applica-

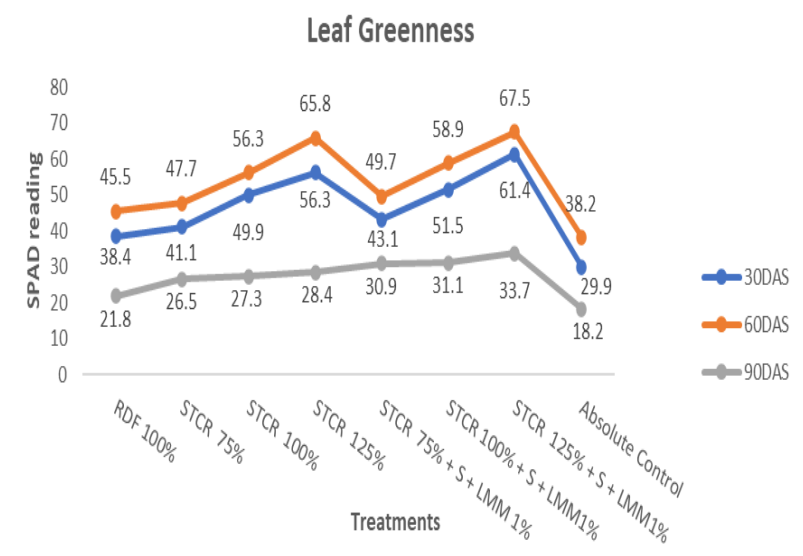

Fig. 2. Fertigation of TNAU-WSF on Leaf Greenness

tion of $125 \%$ NPK as TNAU-WSF with sulphur and LMM (17.51 $\mathrm{t} \mathrm{ha}^{-1}$ ) and which was on par with $\left(\mathrm{T}_{4}\right)$ soil test based application of $125 \%$ NPK (17.32 $\left.\mathrm{t} \mathrm{ha}^{-1}\right)$. Minimum bulb yield was recorded with absolute control $\left(T_{8}\right)$ The increased bulb yield of small onion might be due to improved availability of nutrients in fertigation with TNAU-WSF over surface irrigation and enhanced uptake by small onion. These findings are in line with the findings of Kakade et al. (2015), Bhasker et al. (2018), Babu et al. (2018). The combined application of $\mathrm{N}$ and $S$ had a synergistic effect on bulb yield through better nutrient uptake. Application TNAU LMM attained better bulb yield of onion at $1 \%$ since micronutrients were also responsible for translocation of food materials from leaves to the bulb. These findings agree with Khatemenla et al. (2018), Bharaani et al. (2020).

\section{Effect of TNAU-WSF on Quality parameters Total soluble solids (TSS)}

Fertigation levels significantly influenced total soluble solids (Table 3 ) from $75 \%$ to $125 \%$. TSS of onion bulbs were ranged from 8.91 to 14.78 Brix. Maximum TSS (14.78 ${ }^{\circ}$ Brix) was recorded in $\left(T_{7}\right) 125 \%$ NPK with sulphur and LMM, which was on par with $\left(\mathrm{T}_{4}\right) 125 \%$ NPK as TNAU-WSF recorded $14.14{ }^{\circ}$ Brix. Higher TSS was recorded due to higher application of nitrogen that resulted in enhanced vegetative growth that in turn improved the photosynthetic activity and greater accumulation of carbohydrates in bulbs. Application of TNAU LMM enhances metabolic processes and boosts the biosynthesis of TSS such as carbohydrates, amino acids, and organic acids. More et al. (2017) reported similar findings in onion.

\section{Ascorbic acid}

Increasing the fertigation level from $75 \%$ to $125 \%$ NPK influenced the ascorbic content (Table 3 ) of onion and

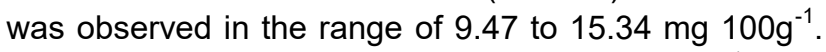
Maximum Ascorbic acid content (15.34 mg $\left.100 \mathrm{~g}^{-1}\right)$ was 
recorded $\left(T_{7}\right)$ in soil test based application of $125 \%$ NPK with $S$ and TNAU LMM (1\%), which was on par with $\mathrm{T}_{4}\left(14.89 \mathrm{mg} 100 \mathrm{~g}^{-1}\right)$. Absolute control recorded

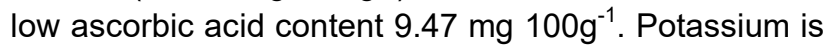
a quality nutrient that is highly responsible for carbohydrate metabolism and thus increases the ascorbic acid content. So, increased application of $\mathrm{K}$ from $75 \%$ to $125 \%$ and application of $S$ at $40 \mathrm{~kg} \mathrm{ha}^{-1}$ might have increased the ascorbic acid content.

\section{Pyruvic acid}

Nitrogen and sulphur had a significant influence on pyruvic acid content (Table 3 ). Soil test based application of $125 \%$ NPK with S and TNAU LMM $(1 \%)\left(T_{7}\right)$ recorded high pyruvic content $\left(2.27 \mu \mathrm{mol} \mathrm{g}^{-1} \mathrm{FW}\right)$, which was on par with soil test based application of $100 \%\left(\mathrm{~T}_{6}\right)$, $75 \%\left(T_{5}\right)$ NPK with S and TNAU LMM. Absolute control recorded low pyruvic acid content of $1.29 \mu \mathrm{mol} \mathrm{g}^{-1} \mathrm{FW}$. The combined application of NPK and $S$ enhances the synthesis of amino acids that act as a precursor for pyruvate synthesis. According to Rumpel et al. (2004), sulphur availability is of key importance for pyruvic acid at adequate nitrogen level. Thangasamy et al. (2013) observed that increase in the application of sulphur from 0 to $50 \mathrm{~kg} \mathrm{ha}^{-1}$ increased pyruvic acid content significantly. This revealed that $\mathrm{N}$ and $\mathrm{S}$ interaction significantly influenced pyruvic acid concentration, particularly at high $\mathrm{N}$ levels.

\section{Economics}

The cost-benefit analysis was worked out (Table 4) for each treatment by dividing gross income with the cost of cultivation-higher gross income of Rs. 4,25,250 ha $^{-1}$ was recorded with $\left(\mathrm{T}_{7}\right)$ soil test based application of $125 \%$ NPK with S at $40 \mathrm{~kg} \mathrm{ha}^{-1}$ and TNAU LMM (1\%). However, soil test based application of $100 \%$ NPK $\left(T_{3}\right)$ recorded a higher benefit-cost ratio (BCR) of 3.52 than $\left(\mathrm{T}_{7}\right)$ soil test based application of $125 \%$ NPK with S and TNAU LMM (1\%) having a benefit-cost ratio of 3.25 (Fig. 3). Soil test based application of $100 \% \operatorname{NPK}\left(\mathrm{T}_{3}\right)$ recorded high yield with $25 \%$ lesser fertilizer input could be the reason for higher $\mathrm{BCR}$ than $\mathrm{T}_{7}$. The findings are

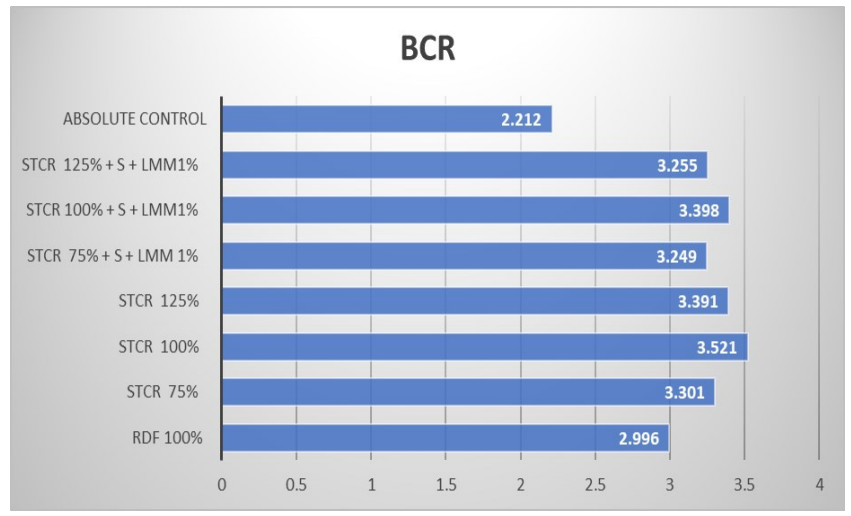

Fig. 3. Benefit-cost ratio of different treatments

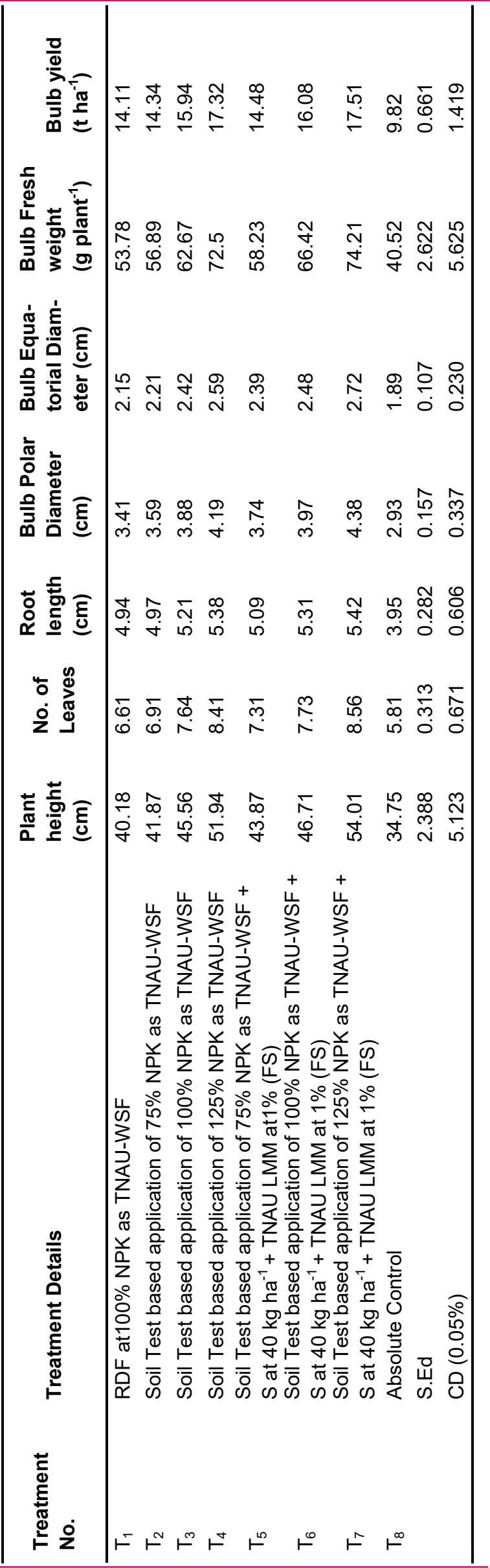


Table 3. Effect of different fertigation levels of TNAU-WSF on the quality attributes of small onion

\begin{tabular}{|c|c|c|c|c|}
\hline $\begin{array}{l}\text { Treatment } \\
\text { No. }\end{array}$ & Treatment Details & TSS ('Brix) & $\begin{array}{l}\text { Ascorbic } \\
\text { acid }(\mathrm{mg} \\
\left.100 \mathrm{~g}^{-1}\right)\end{array}$ & $\begin{array}{l}\text { Pyruvic acid } \\
\text { content ( } \mu \text { mols } \\
\left.\mathrm{g}^{-1} \text { of } \mathrm{FW}\right)\end{array}$ \\
\hline$\overline{\mathrm{T}_{1}}$ & \multirow{2}{*}{$\begin{array}{l}\text { RDF at } 100 \% \text { NPK as TNAU-WSF } \\
\text { Soil Test based application of } 75 \% \text { NPK as } \\
\text { TNAU-WSF }\end{array}$} & 10.69 & 11.12 & 1.4 \\
\hline $\mathrm{T}_{2}$ & & 10.87 & 12.78 & 1.45 \\
\hline $\mathrm{T}_{3}$ & $\begin{array}{l}\text { Soil Test based application of } 100 \% \text { NPK as TNAU- } \\
\text { WSF }\end{array}$ & 13.24 & 13.56 & 1.6 \\
\hline $\mathrm{T}_{4}$ & $\begin{array}{l}\text { Soil Test based application of } 125 \% \text { NPK as TNAU- } \\
\text { WSF } \\
\text { Soil Test based application of } 75 \% \text { NPK as }\end{array}$ & 14.14 & 14.89 & 1.72 \\
\hline $\mathrm{T}_{5}$ & $\begin{array}{l}\text { TNAU-WSF + S at } 40 \mathrm{~kg} \mathrm{ha}^{-1}+\text { TNAU LMM at } 1 \% \\
\text { (FS) }\end{array}$ & 11.15 & 13.16 & 2.04 \\
\hline $\mathrm{T}_{6}$ & $\begin{array}{l}\text { Soil Test based application of } 100 \% \text { NPK as TNAU- } \\
\text { WSF }+S \text { at } 40 \mathrm{~kg} \mathrm{ha}^{-1}+\text { TNAU LMM at1\% (FS) }\end{array}$ & 13.27 & 14.67 & 2.15 \\
\hline $\mathrm{T}_{7}$ & $\begin{array}{l}\text { Soil Test based application of } 125 \% \text { NPK as TNAU- } \\
\text { WSF }+S \text { at } 40 \mathrm{~kg} \mathrm{ha}^{-1}+\text { TNAU LMM at } 1 \%(F S)\end{array}$ & 14.78 & 15.34 & 2.27 \\
\hline \multirow[t]{3}{*}{$\mathrm{T}_{8}$} & Absolute Control & 8.91 & 9.47 & 1.29 \\
\hline & S.Ed & 0.818 & 0.732 & 0.074 \\
\hline & CD $(0.05 \%)$ & 1.756 & 1.571 & 0.16 \\
\hline
\end{tabular}

Table 4. Cost of cultivation of different treatments

\begin{tabular}{|c|c|c|c|c|}
\hline $\begin{array}{l}\text { Treatment } \\
\text { No. }\end{array}$ & Treatment Details & $\begin{array}{l}\text { Cost of } \\
\text { cultivation } \\
\text { (Rs.) }\end{array}$ & $\begin{array}{l}\text { Gross } \\
\text { income } \\
\text { (Rs.) }\end{array}$ & $\begin{array}{l}\text { Net income } \\
\text { (Rs.) }\end{array}$ \\
\hline $\mathrm{T}_{1}$ & RDF at $100 \%$ NPK as TNAU-WSF & 112701 & 337750 & 225049 \\
\hline $\mathrm{T}_{2}$ & Soil Test based application of $75 \%$ NPK as TNAU-WSF & 110941 & 366250 & 255309 \\
\hline $\mathrm{T}_{3}$ & Soil Test based application of $100 \%$ NPK as TNAU-WSF & 116713 & 411000 & 294287 \\
\hline $\mathrm{T}_{4}$ & Soil Test based application of $125 \%$ NPK as TNAU-WSF & 124485 & 422250 & 297765 \\
\hline $\mathrm{T}_{5}$ & $\begin{array}{l}\text { Soil Test based application of } 75 \% \text { NPK as TNAU-WSF } \\
+S \text { at } 40 \mathrm{~kg} \mathrm{ha}^{-1}+\text { TNAU LMM at } 1 \% \text { (FS) }\end{array}$ & 114471 & 372000 & 257529 \\
\hline $\mathrm{T}_{6}$ & $\begin{array}{l}\text { Soil Test based application of } 100 \% \text { NPK as TNAU-WSF } \\
+\mathrm{S} \text { at } 40 \mathrm{~kg} \mathrm{ha}^{-1}+\text { TNAU LMM at } 1 \%(\mathrm{FS})\end{array}$ & 122712 & 417000 & 294288 \\
\hline $\mathrm{T}_{7}$ & $\begin{array}{l}\text { Soil Test based application of } 125 \% \text { NPK as TNAU-WSF } \\
+\mathrm{S} \text { at } 40 \mathrm{~kg} \mathrm{ha}^{-1}+\text { TNAU LMM at } 1 \%(\mathrm{FS})\end{array}$ & 130640 & 425250 & 294610 \\
\hline $\mathrm{T}_{8}$ & Absolute Control & 88750 & 196400 & 107650 \\
\hline
\end{tabular}

in line with the findings of Babu et al. (2018). Therefore, the application of $100 \%$ NPK as TNAU-WSF is recommended in the study area to obtain a higher net profit.

\section{Conclusion}

Response of sulphur and TNAU LMM on yield increase was $0.88 \%$ to $1.77 \%$ over no application of sulphur and TNAU LMM treatments because the experimental soil contains a sufficient amount of sulphur and micronutrients. Though soil test based ap- plication of $125 \%$ NPK with S and TNAU LMM (1\%) $\left(\mathrm{T}_{7}\right)$ increased the bulb yield of $24.10 \%$ over $\mathrm{T}_{1}$ (100\% RDF), it recorded low BCR (3.25) compared to soil test based application of $100 \%$ NPK as TNAUWSF $\left(\mathrm{T}_{3}\right)$ recorded high BCR (3.52). Hence, soil test based application of $100 \%$ NPK as TNAU-WSF $\left(\mathrm{T}_{3}\right)$ was found effective and yield increase over $T_{1}$ (100\% RDF) was $12.97 \%$. Soil test based application of $100 \%$ NPK as TNAU-WSF $\left(\mathrm{T}_{3}\right)$ is advised to farmers to attain economically better bulb yield and quality of a small onion. 


\section{ACKNOWLEDGEMENTS}

The authors sincerely thank the Department of Soil Science and Agricultural Chemistry, Tamil Nadu Agricultural University, Coimbatore. Our profound gratitude also goes to the Th. P. Arunachalam who helped during our research.

\section{Conflict of interest}

The authors declare that they have no conflict of interest.

\section{REFERENCES}

1. Acharya, U., Sharma, N., Rimal, K., Venkatesan, T., Saraswathi, K. \& Subramanian, S. (2015). Response on growth, yield and quality parameters of multiplier onion (Allium cepa L. var. aggregatum Don.) var. CO (On) 5 with different doses and methods of zinc and boron application. Int J Agron and Agril Res, 6(4), 59-67.

2. Agricultural statistics at a glance (2020). Government of India Ministry of Agriculture \& Farmers Welfare Department of Agriculture, Cooperation \& Farmers Welfare Directorate of Economics and Statistics. Retrieved September 08, 2021, https://eands.dacnet.nic.in/PDF/Agricultural \%20Statistics\%20at\%20a\%20Glance\%20-\%202020\%20 (English\%20version).pdf

3. Amare, G. (2020). Review on Mineral Nutrition of Onion (Allium cepa L). The Open Biotechnology Journal, 14 (1),134-144. http://dx.doi.org/10.2174/187407070201401 0134

4. Anthon, G. E. \& Barrett, D. M. (2003). Modified method for the determination of pyruvic acid with dinitrophenylhydrazine in the assessment of onion pungency. Journal of the Science of Food and Agriculture, 83(12), 1210-1213. https://doi.org/10.1002/jsfa.1525

5. Association of Official Analytical Chemists (1995). Official methods of chemical analysis. Association of Official Analytical Chemists (AOAC) Arlington, Virginia, USA.

6. Babu, V. A., Thingalmaniyan, K. S. \& Natarajan, S. K. (2018). Influence of Drip Fertigation on Yield, Quality parameters and Economics of Aggregatum Onion. Madras Agricultural Journal, 105 (1-3), 1. doi:10.29321/MAJ 2018.000192
7. Ballabh, K. \& Rana, D. K. (2012). Response of micronutrients on qualitative and quantitative parameters of onion (Allium cepa L.). Progressive Horticulture, 44(1), 40-46.

8. Bharaani, S. C., Kaleeswari, R. K., Amirtham, D., Vasanthi, D. \& Thavaprakaash, N. (2020). Promotional effect of water soluble fertilizers on growth and yield of lowland rice. Madras Agricultural Journal, 107(4/6), 198-203.

9. Bhasker, P., Singh, R. K., Gupta, R. C., Sharma, H. P. \& Gupta, P. K. (2018). Effect of drip irrigation on growth and yield of onion (Allium cepa L.). J. Spices and Aromatic Crops, 27(1), 32-37. doi: 10.25081/josac.2018.v2 7.i1.10 12.

10. Crop production guide - Horticulture (2020). Tamil Nadu Agricultural University, Coimbatore, Tamil Nadu. Retrieved September 15, 2021, https://tnau.ac.in/research/ wp-content/uploads/sites/60/2020/02/Agriculture-CPG2020.pdf

11. Dingre, S. K. \& Pawar, D. D. (2015). Enhancing productivity of onion seed through fertigation scheduling in western Maharashtra. Vegetable Science, 42(2), 15-20.

12. Gonçalves, F. D. C., Grangeiro, L. C., de Sousa, V. D. F., Santos, J. P. D., Souza, F. I. D. \& da Silva, L. R. (2019). Yield and quality of densely cultivated onion cultivars as function of nitrogen fertilization. Revista Brasileira de Engenharia Agrícola e Ambiental, 23, 847-851. https:// doi.org/10.1590/1807-1929/agriambi.v23n11p847-851

13. Hou, W., Shen, J., Xu, W., Khan, M. R., Wang, Y., Zhou, X. \& Zhang, Z. (2021). Recommended nitrogen rates and the verification of effect based on leaf SPAD readings of rice. PeerJ, 9, e12107. https://dx.doi.org/10.7717\% 2Fpeerj. 12107

14. India Meteorological Department (2021). Ministry of Earth Sciences, Government of India. Retrieved January 23, 2021, https://mausam.imd.gov.in/

15. India Stat (2018). Database management company, New Delhi. Retrieved September 12, 2021, https://www.india stat.com/data/agriculture

16. Jain, G., Kushwah, S. S., Singh, O. P. \& Verma, K. S. (2014). Effect of different doses of nitrogen and sulphur on growth, yield and quality of onion (Allium cepa). Indian J. Agr. Sci, 84(11), 1352-1357.

17. Kakade, S. U., Bhale, V. M. \& Deshmukh, J. P. (2015) Effect of split application of nutrients through fertigation on growth, yield and quality of onion. International Journal of Tropical Agriculture, 33(4 (Part III)), 3279-3283. 